\title{
MATERIAL ANALYSIS OF THE ENGINE PART FOR THE HISTORICAL MOTORCYCLE JAWA 250, 1939
}

\author{
'Lukáš KUDRNA, ²Petra VÁŇOVÁ, ${ }^{2}$ Jitka MALCHARCZIKOVÁ, ${ }^{1 T o m a ́ s ̌ ~ K U B i ́ N ~}$ \\ ${ }^{1}$ VSB - Technical University of Ostrava, Department of Production Machines and Design, Ostrava, \\ Czech Republic, EU, lukas.kudrna@vsb.cz, tomas.kubin@vsb.cz \\ ${ }^{2}$ VSB - Technical University of Ostrava, Department of Material Engineering, Ostrava, Czech Republic, EU, \\ petra.vanova@vsb.cz, jitka.malcharczikova@vsb.cz
}

https://doi.org/10.37904/metal.2020.3594

\begin{abstract}
This article deals with the chemical composition of the engine part mounted on the historical motorcycle JAWA 250 from 1939. Before the company started making motorcycles, it was engaged in the production of firearms. It was an arms industry, and this also entailed high demands on the quality of the products, which can be observed not only on aluminum alloy castings but also on other parts of the motorcycle. The part under review is made of aluminum alloy and serves as a holder for the motorcycle ignition mechanism. It is one of many parts of the engine. There are several reasons for material analysis. The motorcycle was restored, and it was important to find out what material our ancestors used to produce the parts of the motorcycle. The measurement result can be used to produce a new part if necessary, which will be possible to replace either the missing part or the part in an already unrepairable state. The issues concerning the production of spare parts for historical means of transport or technical monuments are generally very extensive. Production processes and materials must be observed. For this reason, material analysis is of great importance and in the future, we will not be able to avoid it in the process of cultural technical monuments restoration. The information found may assist restorers to manufacture or repair of damaged parts. There were more types of JAWA motorcycles produced in the interwar period and the results of this research can be also applied in general.
\end{abstract}

Keywords: Casting, aluminum alloy, composition, historic vehicle

\section{INTRODUCTION}

JAWA motorcycles started to be produced in 1929. Some parts were made in the form of castings. This included, for example, the two-stroke motor parts. JAWA also produced modern four-stroke machines in the 1930s, which also used electron castings. More complex castings, for which more care was paid to the accuracy of production, were contracted out into the company ČKD (Českomoravská Kolben Daněk), which was one of the world's leading technologies in engineering production at that time.

The material analysis consisted of determining the chemical composition of the engine part from the JAWA 250 motorcycle produced in 1939. Specifically, it was an aluminum alloy casting that serves as a holder for ignition.

\section{SAMPLE ANALYSIS}

The chemical composition measurement was carried out using the Delta Professional X-ray spectrometer using the ED-XRF (Energy Dispersive X-ray Fluorescence) method. The first measurement was carried out only on a degreased surface. Due to oxidation of the outer side of the cover, different values were found in the chemical composition of the outer and inner sides of the casting (Table 1). Further measurements were carried 
out after the oxidizing layer was ground (Table 2, Figure 1). It was found that the casting of the engine cover was made of an alloy consisting of $90 \mathrm{wt} \% \mathrm{Al}, 7 \mathrm{wt} \% \mathrm{Cu}, 2.5 \mathrm{wt} \% \mathrm{Si}, 0.5 \mathrm{wt} \% \mathrm{Fe}$. The alloy from which the engine cover was made does not correspond to any of the standard aluminum casting alloys specified in ČSN EN 1706. AICu alloys (EN AC-21000 up to EN AC-21200) contain smaller amounts of copper, i.e. 4.0 to 5.2 $w t \% \mathrm{Cu}$, or eventually $\mathrm{Mg}, \mathrm{Ti}$ and $\mathrm{Mn}$ as additional alloying elements, with a minimum silicon content [1].

The most common foundry alloys are silicon-based alloys, the so-called silumins. Silumins with copper additive $\mathrm{Al}-\mathrm{Si}-\mathrm{Cu}$ are the alloys with the reduced silicon content. They include groups of AISi5Cu (EN AC-45xxx) with a silicon content 4.5-7.0 wt\% and copper of 0.2-5.0 wt\%, or groups of AISi9Cu and AISi (Cu), which have a higher silicon content. In general, they are suitable for the production of impermeable castings, such as petrol engine fittings, carburettors, seals, etc. They are alloys with good foundry properties, do not tend to form cracks in the heat, do not form concentrated shrinkage cavities and are well machinable. The advantage is that they do not absorb gases much. The copper that is present improves its properties at increased temperatures but causes corrosion resistance to worsen. Fluidity of Al-Cu alloys increases with the silicon additive significantly. Alloy AI-Si castability can be improved by adding copper, but machinability deteriorates $[1,2]$.

Copper is considered to be one of the most important elements in aluminum alloys due to its considerable solubility in aluminum and its firming effect. Hardening takes place at low temperatures by heat treatment, at high temperatures alloys with iron, manganese, nickel, etc. are formed. Many industrial aluminum alloys are either a base admixture or they act together with other alloying elements in quantities from 1 to $10 \mathrm{wt} \%$.

The equilibrium binary diagram according to Murray is shown in Figure 2 [2]. The equilibrium phases in the Al-Cu system on both metals form limited rigid solutions $(\mathrm{Cu})$ and $(\mathrm{Al})$ with KPC grid. The solid solution $(\mathrm{Cu})$ is often referred to as $\alpha$ phase. The maximum solubility of copper in a solid aluminum solution is 2.48 at. $\% \mathrm{Cu}$ $(\sim 5.7 \mathrm{wt} \%)$ at the temperature of eutetic reaction $548.2^{\circ} \mathrm{C}$. The microstructure of the alloy under test will consist of a solid solution and a small proportion of eutetic.

Table 1 First measurement on degreased surface

\begin{tabular}{|c|c|c|c|}
\hline \multicolumn{2}{|c|}{ Inside } & \multicolumn{2}{c|}{ Outside } \\
\hline Element & $\begin{array}{c}\text { Average } \\
(\mathrm{wt} \%)\end{array}$ & Element & $\begin{array}{c}\text { Average } \\
(\mathrm{wt} \%)\end{array}$ \\
\hline $\mathrm{Al}$ & 91.02 & $\mathrm{Al}$ & 80.78 \\
\hline $\mathrm{Cu}$ & 5.79 & $\mathrm{Cu}$ & 7.30 \\
\hline $\mathrm{Si}$ & 2.68 & $\mathrm{Si}$ & 11.32 \\
\hline $\mathrm{Fe}$ & 0.39 & $\mathrm{Fe}$ & 0.42 \\
\hline $\mathrm{Mn}$ & 0.04 & $\mathrm{Mn}$ & 0.04 \\
\hline $\mathrm{Ni}$ & 0.01 & $\mathrm{Ni}$ & 0.01 \\
\hline $\mathrm{Mo}$ & 0.01 & $\mathrm{Mo}$ & 0.00 \\
\hline $\mathrm{Zn}$ & 0.07 & $\mathrm{Mg}$ & 0.11 \\
\hline & & $\mathrm{Ti}$ & 0.03 \\
\hline & & $\mathrm{Pb}$ & 0.00 \\
\hline
\end{tabular}

Note: Affected by oxidation, does not include oxygen

The mechanical properties of Al-Cu alloys depend on whether $\mathrm{Cu}$ is present in a solid solution in the form of a spheroid, or possibly as dispersed particles, or whether it creates a net at the border of grains [1]. For the alloy examined, it was possible to measure only the hardness of the casting according to Brinell. The measured hardness was $67 \pm 0.4$ HBW5 (Figure 2). The casting hardness is quite low, thus the casting was probably only in cast state and was not precipitally cured. 

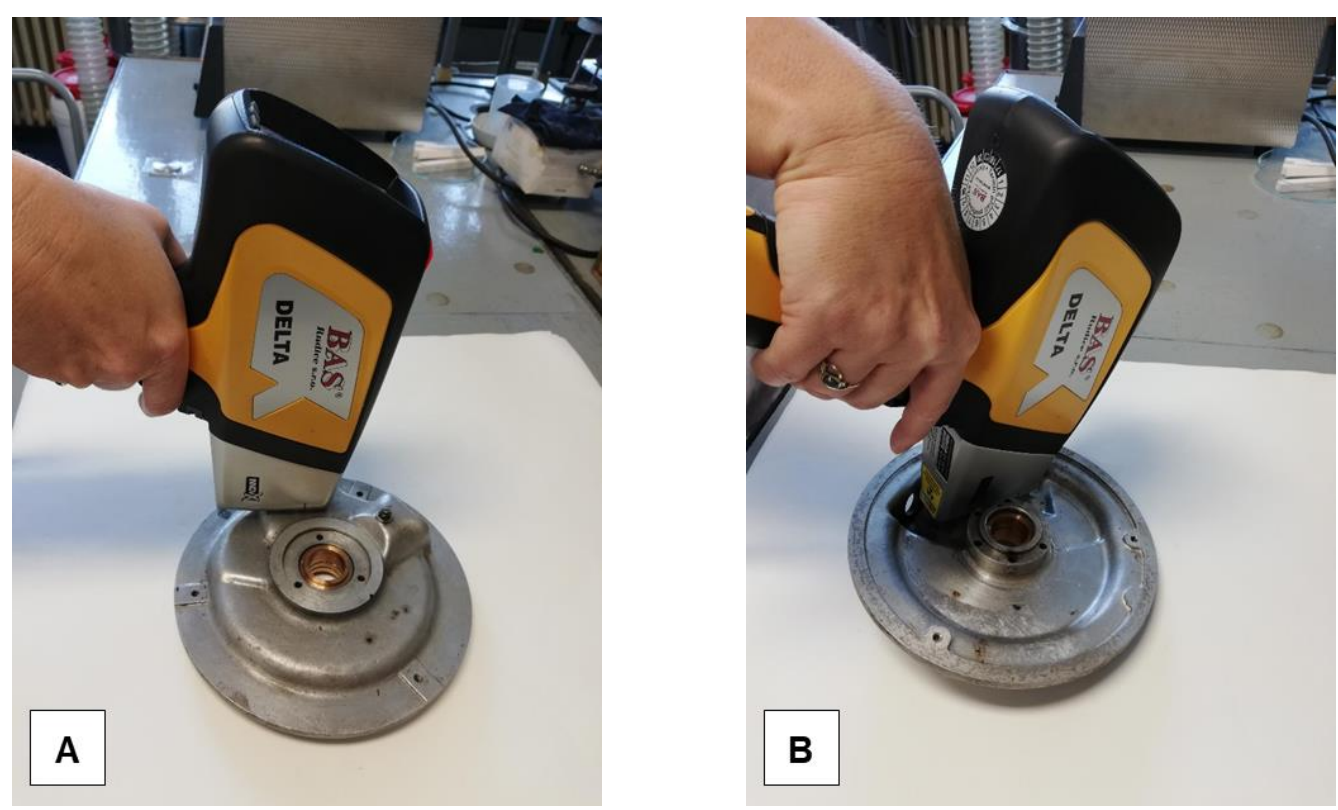

Figure 1 Measurement of chemical composition by ED-XRF method using Delta Professional X-ray Spectrometer A) the outside of the engine cover, B) inside of the engine cover

Table 2 Chemical composition of part - measurement on the ground surface

\begin{tabular}{|c|c|c|c|c|c|}
\hline \multicolumn{2}{|c|}{ Inside } & \multicolumn{2}{c|}{ Outside } & \multicolumn{2}{c|}{ Average chemical composition } \\
\hline Element & $\begin{array}{c}\text { Average } \\
(\mathrm{wt} \%)\end{array}$ & Element & $\begin{array}{c}\text { Average } \\
(\mathrm{wt} \%)\end{array}$ & Element & $\begin{array}{c}\text { Average } \\
(\text { wt } \%)\end{array}$ \\
\hline $\mathrm{Al}$ & 90.13 & $\mathrm{Al}$ & 89.80 & $\mathrm{Al}$ & 89.97 \\
\hline $\mathrm{Cu}$ & 6.96 & $\mathrm{Cu}$ & 7.41 & $\mathrm{Cu}$ & 7.18 \\
\hline $\mathrm{Si}$ & 2.46 & $\mathrm{Si}$ & 2.34 & $\mathrm{Si}$ & 2.40 \\
\hline $\mathrm{Fe}$ & 0.43 & $\mathrm{Fe}$ & 0.42 & $\mathrm{Fe}$ & 0.43 \\
\hline $\mathrm{Mn}$ & 0.01 & $\mathrm{Mn}$ & 0.01 & $\mathrm{Mn}$ & 0.01 \\
\hline $\mathrm{Ni}$ & 0.01 & $\mathrm{Ni}$ & 0.02 & $\mathrm{Ni}$ & 0.01 \\
\hline
\end{tabular}

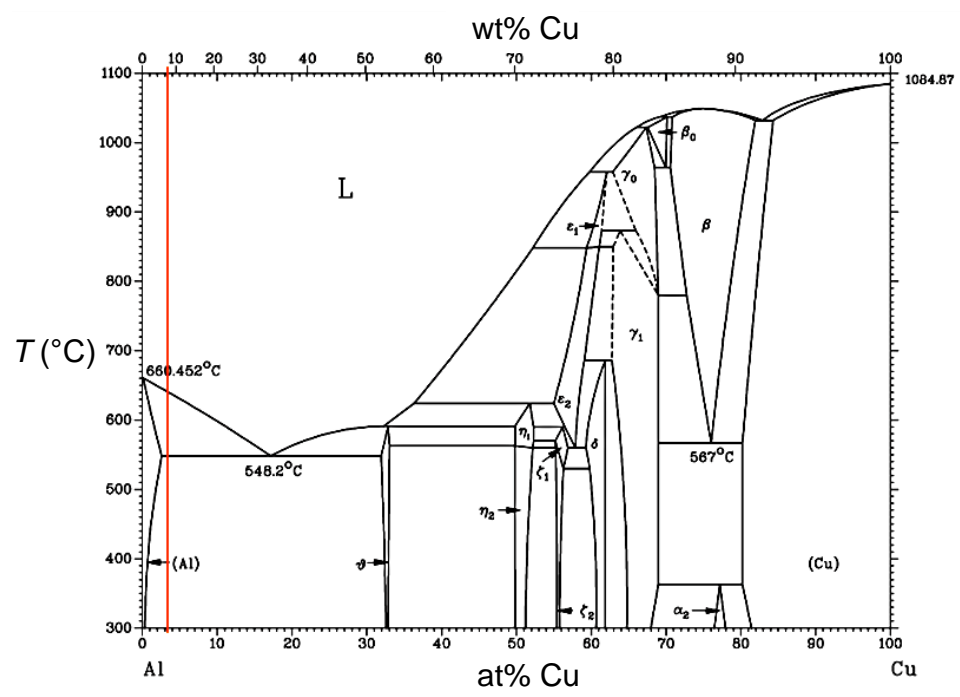

Figure 2 Al-Cu phase diagram with alloy marked 


\section{REVERSE ENGINEERING}

On the engine, we have also used reverse engineering methods. This means that we have modelled or scanned the selected parts and, thus, converted them to digital 3D models. We used reverse engineering methods for the engine head (Figure 3), which in 1939 was made of the same material as the engine cover in question. We focused mainly on castings with aluminum alloys, which cannot be modelled precisely by conventional methods. That is why we have used HandySCAN 3D 700 from Ametek Creaform, which has volumetric accuracy of $0.020 \mathrm{~mm}+0.060 \mathrm{~mm} / \mathrm{m}$. The resulting 3D model can then be printed using additive manufacturing methods to obtain a physical model of the part, which can be further poured using the material from which the original part was made. The part thus obtained has the shape and mechanical properties of the original part, which is a great contribution to the restorers of technical monuments or collectors. These methods will allow us to maintain cultural heritage for future generations [4].

\section{CONCLUSION}

Analysis of the chemical composition of the casting from the engine of the JAWA 250 motorcycle produced in 1939 was made to obtain information about the material that was used to produce the part for the now historical motorcycle. The aim was not to violate the part examined. The result from the measurement can be used as a basis for the production of a new part, which can replace either the missing part or the part in an already unrecoverable state. The issue concerning the production of parts for historical means of transport or technical monuments is generally very extensive. The production processes and material must adhere here. For this reason, material analysis is of great importance and in the future, we cannot avoid it in the restoration of cultural technical monuments. The information found may assist restorers in the manufacture or repair of damaged parts, for example by using of reverse engineering methods $[5,6]$. There were more JAWA motorcycle types produced in the interwar period, so the results of this research can be applied in general.

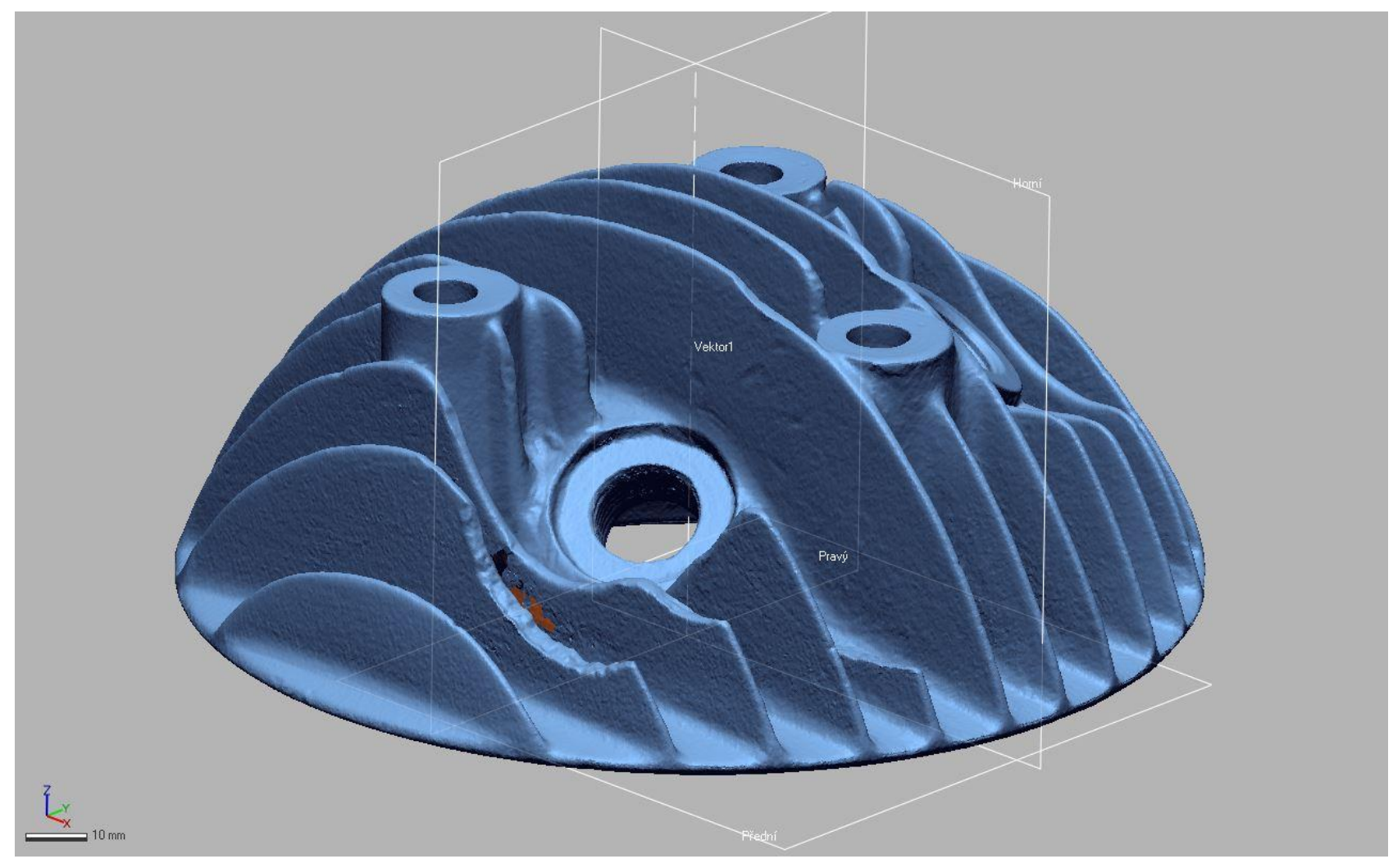

Figure 3 3D scan of the engine head (JAWA 250, 1939) 


\section{ACKNOWLEDGEMENTS}

Innovation of Modern Technologies in Manufacturing Practice, reg. no. SP2020/1 supported by Specific Research program financed by the Ministry of Education, Youth and Sports.

\section{REFERENCES}

[1] ČSN EN 1706: Aluminum and aluminum alloys - Castings - Chemical composition and mechanical properties. Prague: Czech Office for Standards, Metrology and Testing

[2] MICHNA, Š. et al. Encyklopedia of aluminum. (Encyklopedie hliníku). Prešov: Adin, 2005. ISBN 80-89041-88-4. In Czech.

[3] MICHNA, Š. et al. Aluminum materials and technologies from A to Z. Prešov: Adin, 2007. ISBN 978-80-89244-188.

[4] JANČAR, J, PAGÁČ, M., MĚSíČEK, J., STEFEK, P. Design procedure of a topologically optimized scooter frame part. Symmetry. 2020, vol. 13, p. 1527.

[5] DURNA, A., FRIES, J. Universal machine for prototype production. MM Science Journal. March 2020, pp. 37693773. 10.17973/mmsj.2020_03_2019121, WOS:000532576800012.

[6] DURNA, A., FRIES, J., HRABOVSKÝ, L., SLIVA, A., ŽARNOVSKÝ, J. Research and development of laser engraving and material cutting machine from 3D printer. Management Systems in Production Engineering. 2020, vol. 28, no. 1, pp. 47-52. DOI: 10.2478/mspe-2020-0008, WOS:000520868000008. 